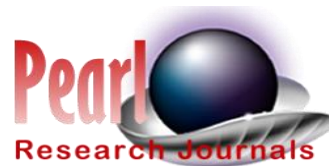

@2020 Pearl Research Journals
Research Journal of Educational Studies and Review Vol. 6 (1), pp. 1-8, March, 2020

ISSN: 2449-1837

Research Paper

https://doi.org/10.36630/rjesr_19025

http://pearlresearchjournals.org/journals/rjesr/index.html

\title{
Evaluation of the Implementation of School Health Programmes in Senior Secondary Schools in Taraba State, Nigeria
}

\author{
Magaji, Peninnah Joseph ${ }^{1 \star}$ and Atando Dauda Agbu ${ }^{2}$ \\ Accepted 19 December 2019 \\ 1Department of General Studies, College of Agriculture, Jalingo, Nigeria. \\ ${ }^{2}$ Department of History and Diplomatic Studies, Taraba State University, Jalingo, Nigeria.
}

\begin{abstract}
This article investigates the level of implementation of the School Health Programmes in Senior Secondary Schools in Taraba State. Schools are important settings for comprehensive health promotion next to the family, exerting the most influence on the lives of the children. However, in Taraba State, health promotion in senior secondary schools seemed to be at its lowest ebb due to lack of synergy between relevant stake holders. Therefore, it is imperative to assess whether or not the implementation of school health programmes in senior secondary schools in Taraba State has helped to promote good health to assist the youth in their academic successes. Using the Descriptive Survey Design, with the aid of Questionnaire, the study revealed that the level of implementation of healthful school environment is moderate in secondary schools in Taraba State; the level of implementation of school feeding services is low in public senior secondary schools and moderate in private senior secondary schools; there is low-level of implementation of skill-based health education and low implementation of school health services among others. The study recommends for effective participation of education stakeholders for the improvement of the wellness of senior secondary students in Taraba State.
\end{abstract}

Keywords: Education, Evaluation, Implementation, School Health Programmes, Senior Secondary Schools, Students, Staff, Stake-holders.

${ }^{*}$ Corresponding author. E-mail: peninnahjosephmagaji@gmail.com. Tel: 08035203043.

\section{INTRODUCTION}

Education and health are two critical issues that have remained topical in developing countries. Ifenkwe (2013) noted that globally, education is regarded as a potent instrument for introducing and sustaining social change in human societies, as well as shaping its destiny. In recognition of the importance of education as a vital tool for sustainable development of both the individual and society, the Federal Government of Nigeria entrenched education as a right of all citizens irrespective of their social, political, religious or economic standings (FRN, 1999). Since the provision of quality education at secondary level is a prerequisite for sustainable national growth and development, the issue of health becomes imperative in secondary schools, as health promotion is key to achieving both Education for All (EFA) and Health for All (HFA) as enunciated by the National School Health Policy (NSHP) 2006. Like many other developing countries, Nigeria has a comprehensive School Health Programme. The programme is defined in the National School Health Policy as a series of harmonized projects/activities in the school environment for the promotion of health and development of the school community (FME, 2006). The components of the School Health Programmes (SHP) vary from country to country, both in structure and in content. The variations though slight, are due mainly to differences in prevailing health problems (Ekenedo and Ekechuckwu, 2015). The SHP as constituted in the NSHP has five components as 
follows: healthful school environment, school feeding services, skilled-based health education, school health services and school, home and community relationship. Each of the components of plays various roles in ensuring the best health environment for effective learning. It is against the background that this paper evaluates the level of implementation of the School Health Programmes in Senior Secondary Schools in Taraba State of Nigeria.

\section{METHODOLOGY}

The research design adopted for this study is Descriptive Survey Design. According to Nworgu (2006) survey design is one in which a group of people or items are studied by collecting and analysing data from only a few people or items considered to be representative of the entire group. In this research, the adoption of the survey design enabled the researchers to collect data from sampled respondents with the aid of a questionnaire. The design also aided the researchers to collect data from respondents with relevant knowledge of the level of implementation of the school health programme in Taraba State Senior Secondary Schools. The population of this study comprised of 13,018 teachers in the 204 Senior Secondary Schools of the eight education zones in Taraba State. Table 1 shows that there is a population of 110 public Senior Secondary Schools and 94 private Senior Secondary Schools in the eight (8) education zones in Taraba State. The table also shows that there is a population of 9,861 public Senior Secondary School teachers and 3,157 private Senior Secondary School teachers. The sample size consisted of 20 Senior Secondary Schools (11 public senior secondary schools and 9 private senior secondary schools) being $10 \%$ of the 204 senior secondary schools in the eight educational zones in Taraba State and 709 teachers sampled from the 20 senior secondary schools selected. To arrive at the appropriate sample size for respondents (teachers), the researchers made use of the Krejcie and Morgan (1970) table for determining sample sizes. According to the table, a finite population size of 9,000 to 9,999 should elicit a sample size of 368 respondents, while a population size of 3,000 to 3,499 should elicit a sample size of 341 respondents. The sampling technique adopted was proportionate random sampling. This technique was considered suitable for distribution of the 20 sampled senior secondary schools and 709 sampled senior secondary schools' teachers for the purpose of achieving proper representation as well as even and fair spread of the samples across the eight education zones in Taraba State. In justifying the use of proportionate sampling technique, Nworgu (2006) noted that proportionate random sampling technique allows for greater representativeness of the population using the sample size selected. Thus, the technique ensured proper distribution and representation of the sampled senior secondary schools and teachers in the research.
Balloting process was used by the researchers to ensure that all the senior secondary schools and teachers stand equal chance of being selected for the research (Table 2).

The research instrument used for this study was a researcher constructed questionnaire titled, "Assessment of School Health Programme Implementation Questionnaire" (ASHPIQ). The ASHPIQ was a modified 4-point Likert type rating scale options such as High Level (HL), Moderate Level (ML), Low Level (LL), and Very Low Level (VLL). The ASHPIQ was made up of two sections ( $A$ and $B$ ). Section $A$ contained information on school type (Public / Private). Section B contained 30 items. Out of the 30 items, 10 items assessed the implementation of healthful school environment, 5 items assessed the implementation of school feeding services, 5 items assessed the implementation of skill-based health education, 5 items assessed the implementation of school health services, and 6 items assessed the implementation of school, home and community relationship in senior secondary schools in Taraba State. The researchers collected the data from respondents directly with the aid of the research instrument. The researchers were assisted during the exercise by four research assistants who were briefed on how to administer the instrument on sampled respondents in their various secondary schools. The copies of the questionnaire were collected on the spot to ensure a high rate of retrieval. The data analysis for the study was done using frequencies and percentages for the personal data. Mean scores and standard deviation were used to answer the research questions generated in the study. The null hypotheses were tested using t-test statistics being a test of difference between two sets of measurements. As decision rule, any mean score of 2.50 and above signifies agreement while mean scores below 2.50 show disagreement. The weights of the responses were; HL (Four points), ML (Three points), LL (Two points), and VLL (One point). For a better interpretation of results, high level of implementation fell between 3.25 to 4.00 , ML was rated from 2.50 to 3.24 , LL was between 1.75 to 2.49 , and VLL was rated from 1.00 to 1.74 . The validity of the research instrument was ascertained by professionals in the Department of Educational Management, University of Abuja, Nigeria. They made observations on the questionnaire and corrections were effected. The reliability of the instrument was done through a pilot test using 20 teachers from 2 senior secondary schools in Taraba State which are excluded from the study. Thereafter, split-half method and Pearson Product Moment Correlation Coefficient (PPMCC) was used to compute the reliability index. A reliability index of 0.78 was obtained. To determine the actual reliability, an estimate of the pilot test, the Spearman-Brown prediction formula was applied. This yielded a reliability coefficient of 0.88 . This indicated the reliable nature of the instrument for the study. According to Olayiwola (2007), a reliability index of 0.50 to +1 is appropriate for a research of this nature. 
Table 1. Education zones, population of public and private senior secondary schools and teachers.

\begin{tabular}{llcccc}
\hline S/N & Education Zones & $\begin{array}{c}\text { No. of Public Senior } \\
\text { Secondary Schools }\end{array}$ & $\begin{array}{c}\text { No. of Private Senior } \\
\text { Secondary Schools }\end{array}$ & $\begin{array}{c}\text { No. of Public Senior } \\
\text { Secondary School Teachers }\end{array}$ \\
\hline Secondary School Teachers
\end{tabular}

Source: Taraba State Post Primary Schools Management Board (2014/2015).

Table 2. Education zones, sampled public and private senior secondary schools and teachers (based on Krejcie and Morgan (1970) table of sample size).

\begin{tabular}{|c|c|c|c|c|c|c|c|c|}
\hline $\begin{array}{l}\text { Education } \\
\text { Zones }\end{array}$ & $\begin{array}{l}\text { No. of Public } \\
\text { Senior } \\
\text { Secondary } \\
\text { Schools }\end{array}$ & $\begin{array}{l}\text { No. of Sampled } \\
\text { Public } \\
\text { Secondary }\end{array}$ & $\begin{array}{l}\text { No. of Private } \\
\text { Senior } \\
\text { Secondary } \\
\text { Schools }\end{array}$ & $\begin{array}{l}\text { No. of Sampled } \\
\text { Private Senior } \\
\text { Secondary Schools }\end{array}$ & $\begin{array}{l}\text { No. of Public } \\
\text { Senior Secondary } \\
\text { School } \\
\text { Teachers }\end{array}$ & $\begin{array}{l}\text { No. Of Sampled } \\
\text { Public } \\
\text { Senior Secondary } \\
\text { School Teachers }\end{array}$ & $\begin{array}{l}\text { No. of private } \\
\text { senior } \\
\text { secondary } \\
\text { school teachers }\end{array}$ & $\begin{array}{l}\text { No. of sampled } \\
\text { private senior } \\
\text { secondary school } \\
\text { teachers }\end{array}$ \\
\hline Jalingo & 22 & 2 & 15 & 2 & 2,112 & 79 & 840 & 91 \\
\hline Wukari & 18 & 2 & 11 & 1 & 1,728 & 64 & 506 & 55 \\
\hline Sardauna & 15 & 2 & 12 & 1 & 1,380 & 51 & 456 & 49 \\
\hline Bali & 10 & 1 & 8 & 1 & 889 & 33 & 291 & 31 \\
\hline Karim-lamido & 10 & 1 & 9 & 1 & 765 & 29 & 162 & 17 \\
\hline Gassol & 12 & 1 & 10 & 1 & 1,052 & 39 & 283 & 31 \\
\hline Takun & 11 & 1 & 13 & 1 & 964 & 36 & 302 & 33 \\
\hline Zing & 12 & 1 & 14 & 1 & 971 & 36 & 317 & 34 \\
\hline Total & 110 & 11 & 94 & 9 & 9,861 & 368 & 3,157 & 341 \\
\hline
\end{tabular}

\section{THEORETICAL FRAMEWORK OPERATIONAL TERMS}

This article is anchored on Don Elger's and Bransford's theories of performance. Don Elger (2000), sees performance from the based word 'perform'. To perform is to produce valued results. A performer can be an individual or group of individuals, engaged in a collaborative effort.
According to this theory, developing performance is a journey and the level of performance describes the location in the journey (Caine et al., 2005). Don Elger's conditions for optima/performance and improvement in performance can be synthesized in three Axioms: Axiom 1- Engage the performer in an optimal emotional state which he referred to as "performers' state of mind". Performers' state of mind includes actions that engage positive emotions, setting challenging goals, allowing failure as a natural part of attaining high performance and providing conditions in which the performer feels secured.

Axiom 2 - Immerse the performance in an enriching environment. This has to do with immersion in a physical, social and intellectual environment which can elevate performance and stimulate both personal and professional development using 
elements of social interaction, interdisciplinary knowledge, active learning and emotions and spiritual alignment. Axiom 3 - Engage the performer in reflective practice. Reflective practice involves actions that help people to pay attention to the environment and learn from the environment by observing the present level of performance, noting accomplishment and analysing strengths as well as areas of improvement. In support of Elger's performance theory, Bransford developed a model for effective teaching and learning to buttress more on Don Elger's assumption of immersion, adding that improvement in performance includes improvement in knowledge-center and community center components which connote immersion in an enriching environment, while the assessment center component embraces elements of effective practices (Brown and Cocking, 2000). Contributions supporting this theory can also be found in the work of Caine et al. (2005), which added that relaxed alertness aligns with the performer's mindset orchestrated involvement with immersion action, processing of experiences and also aligns with reflective practices to improve performance. To enhance these themes of performance, the principals and teachers have to work hard by improving their own performance, empowering themselves to help the improvement and growth of health practices in secondary schools and becoming a 'self-grower' as advocated by Harvard's Project Zero, performance closely related to learning-forunderstanding (Wiske, 1998). Thus, it is necessary to advocate performance building capabilities as central in school health issues. The relevance of the theories to this study is based on the fact that they support the promotion of school health and considers the implementation of school health programmes as a means to achieving better performance from members of the school community.

\section{Operational Terms}

The following terms used in the paper are defined operationally as follows:

\section{School Health}

Refers to a state of physical, mental and social well-being of teachers, students, school management and community members, though the use of health practices that ensure schools are healthy places in which to live, learn and work.

\section{School Health Promotion}

Refers to evidence-based interventions by the school management, students, parents, staff and community members, aimed at facilitating healthful school environment, school feeding services, skill-based health education, school health services, as well as school, home and community relationships in senior secondary schools in Taraba State.

\section{Healthful School Environment}

Refers to all the consciously organized planned and executed efforts to ensure safety and healthy living conditions for all members of the school community in senior secondary schools in Taraba State.

\section{School Feeding Service}

Refers to a set of organized activities aimed at providing an adequate meal a day to all children enrolled in schools as a means to improving their nutritional levels, increase school enrolment, attendance, retention and completion rates in senior secondary schools in Taraba State.

\section{Skill-Based Health Education}

Refers to the promotion and development of sound health knowledge, attitudes, skills, appropriate behaviours and practices among learners in senior secondary schools in Taraba State.

\section{School Health Services}

Refers to assistance given to teachers and students by government and educational stakeholders through the provision of preventive and curative services aimed at achieving maximum health among them in senior secondary schools in Taraba State.

\section{School, Home and Community Relationship}

Refers to building and strengthening capacity for effective community involvement and participation in school health promotion in senior secondary schools in Taraba State.

\section{Models of School Health Programmes}

There are a variety of models that have been used to describe the components of a school health programme. Three of the commonest are summarized as follows:

i. The Three Component Model: Originating in the 1900s and evolving through the 1980s, the three-component model is considered the traditional model of school health programme, consistory of basic components such as health education; health services; and healthful school environment (Dryfoos, 1994; National Academy of Science, 2010).

ii. The Eight Component Model: In the 1980s, the threecomponent model was expanded into an eightcomponent model, traditionally referred to as a comprehensive school health programme. It consists of the following components: health education; physical education; health services; nutritional services; health promotion of staff; counseling, psychological and social services; health school environment; and finally, parent and community involvement (Dryfoos, 1994; National Academy of Science, 2010). 
iii. The Full-Service School Model: This is a recent model in the evolution of school health programmes. Under this model, the charge to the community is to bring into the school a wide range of services, including health, mental health, employment services, child-care, parent education, case management, recreation, cultural events, welfare, community policing and whatever else may fit into the picture based on the needs of the community. The result is a type of 'one-stop' systemfacilities that can offer a seamless experience for the students, parents and staff (Dryfoos, 1994; National Academy of Science, 2010).

\section{The School Health Programmes in Nigeria}

The school health programme in Nigeria is captured in the National School Health Policy (2006). The main goal of the programme is to improve the health of learners and staff as responsible and productive citizens. A comprehensive school health programme is an integrated set of planned, sequential, school-affiliated strategies, activities and services designed to promote the optimal physical, emotional, social and educational development of students.

The programme involves and is supportive of families and is determined by the local community based on community needs, resources, standards and requirements.

It is coordinated by a multidisciplinary team and accountable to the community for programme quality and effectiveness (CCHP, 2005). Simply put, school health programme refers to all aspects of the school programmes which contributes to the understanding, maintenance and improvement of the health of the school population (Akani et al., 2001). An effective school health programme can be of the most effective investment a nation can make to improve education and health simultaneously. Promoting school health programme is imperative as it is a means to preventing important health risks among the youth and to engage the education sector in efforts to charge the educational, social, economic, and political conditions that affect risk (WHO, 2008). When effectively managed, school health services have yielded significant contributions in school base health programmes (Ajuwon and Brieger, 2017; Ayi et al., 2010); health-related intervention feeding (Ekpo et al., 2008); smoking cessation programmes (Falade, 2012), and so on. In Nigeria, the National School Health Policy was introduced in 2006, to improve the state of school health services in the country. Despite the fact that it emphasizes the advantage of school health services, emergency care and first aid services, the embrace of proper and effective health services in school is yet to be fully imbibed (Ofovwe and Ofili, 2007).

Thus, the promotion of school health is a critical aspect of the school principal's activities. Emerging evidence indicates that principals have a significant influence on whether to or not a school will become and remain a healthy organization.

\section{RESULTS}

From the investigation carried out (Magaji, 2018), based on teachers' assessment of healthful school environment in the public senior secondary schools in Taraba State, the following have been implemented at moderate level: classrooms and learning spaces are decongested of harmful materials and objects; brooms, dustbin, mopping sticks, wash-hand equipment's are provided for school sanitation; toilets and latrines are sufficiently provided and gender-sensitive; provision of recreational and sport facilities such as playing ground and sport field for psychomotor development of students is prioritized; adequate amount of furniture for teaching and learning of students are made available; and teachers and students are sensitized on the hazards associated with exposure to excessive noise, heat and cold. Again, according to the teachers (Magaji, 2018), the following aspects of healthful school environment have low level of implementation: the provision of boreholes and wells for regular and safe water supply; provision of proper drainage and waste disposal facilities; provision of perimeter fencing for security of students and staff; and organization and observation of annual school health days. Thus, it is established that the level of implementation of a healthful school environment is moderate in public senior secondary schools in Taraba State (Magaji, 2018). On the part of private senior secondary schools in Taraba State, based on teachers' assessment, the following have been implemented at moderate level: classrooms and learning spaces are decongested of harmful materials and objects; brooms, dustbin, mopping sticks, wash-hand equipment's are provided for school sanitation; toilets and latrines are provided and gender-sensitive; provision of recreational and sport facilities such as playing ground and sports field for psychomotor development of students is prioritized; security for staff and students through perimeter fencing; annual school health days are observed and organized; adequate amount of furniture for teaching and learning of students are made available, and teachers and students are sensitized on the hazards associated with exposure to excessive noise, heat and cold. However, the teachers in private senior secondary schools in Taraba State tended to agree that the implementation of boreholes and wells for regular and safe water supply is low. Thus, it can be established that the level of implementation of a healthy school environment is moderate in private senior secondary school in Taraba State.

On the level of implementation of school feeding services in public and private secondary schools in the state, based on teachers' assessment, the following have been implemented at moderate level in public senior secondary schools: students and teachers involvement in farm activities are promoted; workshops are organized in partnership with parent and health practitioners to sensitize students and teachers on the importance of nutrition to effective teaching and learning. Low level of 
implementation at the public senior secondary school of the following: food handlers prioritize sanitation and hygiene practices at all times; regular de-worming for students is emphasized, and healthy eating habits among teachers and students is encouraged and enforced. At the private senior secondary schools, while the implementation of workshops in order to sensitize students and teachers on the importance of nutrition to effective teaching and learning is low, the following have been implemented at moderate level: students and teachers involvement in farm activities are promoted; food handlers prioritize sanitation and hygiene practices at all times, regular de-worming for students is emphasized; healthy eating habits among teachers and students is encouraged and enforced. Specifically, the conclusions are that while the implementation of school feeding services in public senior secondary schools in Taraba State is at low level; it is at a moderate level in private senior secondary schools in the state (Magaji, 2018). On the level of implementation of skill-based health education in public and private senior secondary schools in Taraba State, teachers' assessment revealed that the following have been implemented at low level in the public schools: health behavioural goals are set for school personnel and students; counseling for teachers, students and community members is organized based on preventive health measures; information in key health issues affecting the school community is disseminated in order to prevent outbreak of epidemics; training programmes for teachers, community members and students on health practices; and community health are regularly organized; and health-based knowledge, attitude, habits of teachers and students are enhanced and monitored.

In the private senior secondary schools, the assessment revealed the following have been implemented at low level also: human behavioural goals are set for personnel and students; counselling for teachers, students and community members are organized based on preventive health measures; information on key health issues affecting the school community is disseminated in order to prevent outbreak of epidemics; training programmes for teachers community members and students on health practices and community health are regularly organized; health-based knowledge, attitudes, habits of teachers enhanced and monitored. Therefore, based on the assessment above for both public and private senior secondary schools in Taraba State, there is a low level of implementation of skill-based health education (Magaji, 2018). About the extent of implementation of school health services in both public and private senior secondary schools in Taraba State, the following have been implemented at low level in public senior secondary schools: the school clinic and sickbay are equipped with first aid kits and drugs; regular health and medical examination for teachers and students are organized; health practitioners collaborate with educational personnel in providing health counseling for the school community on sensitive health services; health records of teachers and students are maintained and upgraded regularly; medical referrals and follow-up health services for schools personnel and students are made available; prevention and control of communicable and noncommunicable diseases is emphasized and made a priority. In the private senior secondary schools, the following have been implemented at moderate level: the school clinic and sickbay are equipped with first aid kits and drugs; regular health and medical examinations for teachers and students are maintained and updated regularly, and prevention and control of communicable and non-communicable diseases is emphasized and made a priority. On the low level, implementation in private senior secondary schools is on the following: health practitioners collaborate with educational personnel in providing health counseling for the school community on sensitive health issues, and medical referrals and follow-up health services for school personnel and students are made available. Consequent on the assessment of the level of implementation of school health services in public and private service secondary schools in Taraba State by teachers, the level of implementation generally in public senior secondary schools is low while the level of implementation in private senior secondary school is also low (Magaji, 2018). Finally, on the level of the implementation of school, home and community relationship in public and private senior secondary schools in Taraba State, the assessment of teachers in public senior secondary school indicated that low level of implementation is in the following areas: home visits by teachers, school nurses and social workers are promoted; and the community is involved in promoting of health-related school policies, while moderate level of implementation was recorded on; regular visits of parents to the school is made compulsory; and active participation of the school in community health planning, implantation and evaluation is encouraged. On the part of private senior secondary schools all final decision was low. Therefore, the level of implementation of school, home and community relationships in both public and private senior secondary schools in Taraba State is low (Magaji, 2018).

\section{DISCUSSION}

From the investigation so far, it is clear that the following are correct on the implementation of school health programmes in senior secondary schools in Taraba State:

1. There is a moderate level of implementation of healthful school environment in public and private senior secondary schools in Taraba State. From the assessment of teachers in both public and private schools, there is a low level of implementation of aspects of healthful school environments such as the provision of boreholes and wells for regular and safe water supply. 
2. Also, in public schools, the level of implementation of drainage and waste disposal facilities, perimeter fencing for security of students and staff, and annual school health days were found to be low. This finding negates the objectives of healthful school environment as stated in the National School Health Policy (2006), which is to create a healthy and safe learning environment in the schools and provide adequate safe water supply and sanitation facilities for use in schools.

3 . There is a low level of implementation of school feeding services in public senior secondary schools; a moderate level of implementation in private senior secondary schools in Taraba State. From the assessment of teachers, their output indicated that in public schools, there is low level of implementation of school feeding services in areas such as involvement of students and teachers in farm activities. In both public and private schools, organization of workshops in partnerships with parent and health practitioners to sensitize students and teachers on the importance of nutrition to effective teaching and learning has been poorly implemented. This is similar to the findings of Ademokun et al. (2014) who observed that in SouthWestern secondary schools, the implementation of feeding services is low and could be improved upon.

4. There is a low level of implementation of skill-based health education in both public and private senior secondary schools in Taraba State. The assessment showed that the level of implementation reflected in areas such as setting health behavioral goals for school personnel and students, organizing counseling for teachers, students and community members on preventive health measures, disseminating information on key health issues affecting the school community as a means to prevent outbreak of epidemics, organizing regular training programmes for teachers, community members and students on health practices and community health, enhancing and monitoring healthbased knowledge, attitudes and habits of teachers and students, are all low. This conforms to the results of Idehen and Oshodin (2008) that the health education curriculum is not adequately implemented in secondary schools in Edo State. In Taraba State, adequate efforts have not been made in the implementation of school health programmes.

5. Furthermore, there is a low level of implementation of school's health services in public and private senior secondary schools in Taraba State. Evaluation of the public schools revealed low implementation of school health service such as equipping school clinic and sickbay with first aid kits and drugs, organizing regular health and medical examination for teachers and students, collaboration of health practitioners and educational personnel in providing health counseling for the school community on sensitive health issues, maintaining and updating health records of teachers and students, availability of medical referrals and follow-up health services for school personnel and students, preventive and control of communicable and non- communicable diseases. In private schools, the results showed that there is a moderate level of implementation of school health services, except for collaboration between health practitioners and educational personnel in providing health counseling for the school community on sensitive health issues and availability of medical referrals and follow-up health services for school personnel and students which implementation is low. In the South-Western secondary schools, Ademokun et al. (2014), found that the implementation of school health services is poor in secondary schools.

6 . Finally, it is revealed that in both public and private senior secondary schools in Taraba State, the school, home and community relationship component of the National School Health Policy had a low level of implementation. The assessment confirmed that in public schools, regular visits of parent to the school is made compulsory and active participation of the school community health planning implementation, monitoring is encouraged. In the case of private schools, the result indicated that it is the components of the NSHP that had the lowest level of implementation in private schools in Taraba State. The implication is that both public and private senior secondary schools in Taraba State have failed to achieve the objectives of promoting school, home and community relationships with regards to school health. Thus, the outcome of the investigation generally revealed that the level of implementation of the five components of the NSHP did not differ significantly in public and private senior secondary schools in Taraba State and it is not influenced by the school type or ownership. None of the five components have a high level of implementation.

\section{CONCLUSION/RECOMMENDATIONS}

The following recommendations are made based on the outcome of the study:The implementation of healthful school environment in senior secondary schools in Taraba State can be improved on by education stakeholders in the public and private sector through provision of boreholes and water-wells for regular and safe water supply, provision of proper drainage and waste disposal facilities, provision of security for students and staff through perimeter fencing, and organizing annual school health day. In the implementation of school feeding services in public senior secondary schools in Taraba State, education stakeholders should emphasize the involvement of students and teachers in farm activities; sensitization of students and teachers on the importance of nutrition through workshops. In both public and private senior secondary schools in Taraba State, skill-based health education can be improved through more skilled manpower and recruiting health instructors by the school authorities to enhance healthbased knowledge, attitudes and habits of teachers and students.

School health services should be better improved in both 
public and private senior secondary schools in Taraba State through constant screening and immunization of both teachers and students in the state by the school authorities in order to achieve efficient and effective school health service delivery. The implementation of school, home and community relationship should be prioritized by education stake-holders through promoting home visits by teachers, school nurses and social workers; involving school community in promotion of health-related school policies, and active participation of the school in community health planning, implementation, monitoring and evaluation in senior secondary schools in Taraba State. Therefore, there is a need for school principals to address the low level of implementation of the school health programmes in their schools through advocacy and creating synergy with Parent Teachers' Association (PTA), and School-Based Management Committees, (SBMCs). Also, there is the need for principals to devote substantial resources to the implementation of school health programmes in its entirety due to the interdependence of the components of the school health policy. Finally, for education planners, there is a need for a consistent review of the level of implementation of the NSHP in schools, collaborate with education stakeholders in ensuring that schools have the overall capacity to implement the school health programmes, thereby becoming healthpromoting schools.

\section{REFERENCES}

Ademokun OM, Kayode OO, Taiwo AO (2014). A Qualitative Study on Status of Implementation of School Health Programme in SouthWestern Nigeria: Implications for Healthy Living of School-Age Children in Developing Countries. American Journal of Educational Research. 2(11): 1076-1087.

Ajuwon AJ, Brieger WR (2007). Evaluation of a School-Based Reproductive Health Education Program in Rural South Western, Nigeria. African Journal of Reproductive Health. 11(2): 47-59.

Akan NA, Nkanginiene KEO, Oruamabo RS (2001). The School Health Programme: A Situational Revisit. Niger Journal of Paediatrics. 28(1): $1-6$.

Ayi I, Nonaka D, Adjovu JK, Hana Fusa S, Jimba M, Bosompem KM (2010). School-Based Participatory Health Education for Malaria Control in Ghana: Engaging Children as Health Messengers. Malaria Journal. 9:98.
Brown AL and Cocking RR, (Eds.), (2000). How People Learn, National Academy Press Washington Dc.

Caine RN, Caine G, McClintic C, and Klimek K (2005). 12 Brain/Mind Learning Principles in Action. Crow in Press, Thousand AOKS, L.A.

Committee on Comprehensive School Health Programs (2005). Defining a Comprehensive School Health Program: An Interim Statement. World Health Organization, Geneva.

Don E (2000). Theory of Performance. University of Idoho. http://www.Google, theory of Performance (Accessed on May 10, 2014.

Dryfoos JG (1994). Full-Service Schools: A Revolution in Health and Social Services for Children, Youth and Families. Jossey-Bass Publishers, San Francisco, California.

Ekenedo GO, Ekechukwu RO (2015). Achieving Better Educational Outcomes in Nigeria through the School Health Programme. European Journal of Research and Reflection in Educational Sciences, 3(5): 52-63.

Ekpo UF, Odoemene SN, Mafiana CF, Sam-Wobo SO (2008). Helminthiasis and Hygiene Conditions of Schools in Ikenne, Ogun State, Nigeria. Tropical Discourse Journal, 2(1): 34-43.

Falade OS (2012). School Feeding Programme in Nigeria: The Nutritional Status of Pupils in a Public Primary School in lle-Ife, Osun State, Nigeria. Journal of Food and Nutrition Sciences, 3(2): 596-605.

Federal Ministry of Education (2006). Implementation Guideline on National School Health Programme. Federal Republic of Nigeria, Abuja.

Federal Republic of Nigeria (1999). Constitution of the Federal Republic of Nigeria. FGN, Abuja.

Idehen CO, Oshodin OG (2008). Factors Affecting Health Instruction in Secondary Schools in Edo State, Nigeria. Journal of Medicine, 2(1): 61-66.

Ifenkwe GE (2013). Educational Development in Nigeria: Challenges and Prospects in the $21^{\text {st }}$ Century. Universal Journal of Education and General Studies, 2(1): 007-014.

Magaji PJ (2018). Assessment of the Implementation of School Health Programme in Senior Secondary Schools in Taraba State, Nigeria. Unpublished Dissertation in Partial Fulfilment of the Requirement for the M.Ed, University of Abuja, Nigeria.

National Academy of Sciences (2010). Evolution of School Health Programs: Defining a Comprehensive School Health Programme. National Academies Press, Washington DC.

Nworgu BG (2006). Educational Research: Basic Issues and Methodology. University Trust Publishers, Nsukka.

Olayiwola AO (2007). Procedures in Educational Research. Hanyan Pub. Ltd, Kaduna.

World Health Organization, 2008. Regional Strategy for Health Promotion for South East Area: South East Asia Regional Office: WHO. 